\title{
The Story of Vibe Magazine's TLC Cover: How it Helps to Explain Race, Representation and Resistance from Journalism's Hip-Hop Generation
}

\section{Vinita Srivastava}

Ryerson University

Srivastava, V. (2012). The story of Vibe Magazine's TLC Cover: How it helps to explain race, representation and resistance from journalism's hip-hop generation. International Journal of the Image, 2(1), 57-66.

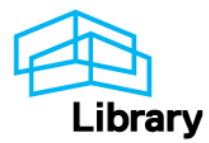




\section{THE INTERNATIONAL}

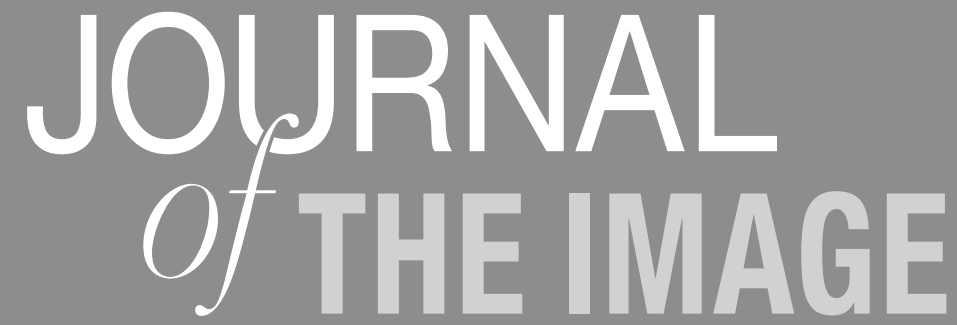

Volume 2, Issue 1

The Story of Vibe Magazine's TLC Cover: How it Helps to Explain Race, Representation and Resistance from Journalism's Hip-hop Generation

Vinita Srivastava 
THE INTERNATIONAL JOURNAL OF THE IMAGE http://ontheimage.com/journal/

First published in 2012 in Champaign, Illinois, USA

by Common Ground Publishing LLC

www.CommonGroundPublishing.com

ISSN: 2152-7857

(C) 2012 (individual papers), the author(s)

(c) 2012 (selection and editorial matter) Common Ground

All rights reserved. Apart from fair dealing for the purposes of study, research, criticism or review as permitted under the applicable copyright legislation, no part of this work may be reproduced by any process without written permission from the publisher. For permissions and other inquiries, please contact

<cg-support@commongroundpublishing.com>.

THE INTERNATIONAL JOURNAL OF THE IMAGE is peer-reviewed, supported by rigorous processes of criterion-referenced article ranking and qualitative commentary, ensuring that only intellectual work of the greatest substance and highest significance is published.

Typeset in Common Ground Markup Language using CGPublisher multichannel typesetting system

http://www.commongroundpublishing.com/software/ 


\title{
The Story of Vibe Magazine's TLC Cover: How it Helps to Explain Race, Representation and Resistance from Journalism's Hip-hop Generation
}

\author{
Vinita Srivastava, Ryerson University, Ontario, Canada
}

\begin{abstract}
This paper is a case study of one Vibe magazine cover. The examination of this cover, which depicts multiplatinum girl band TLC, serves to provide an analytical framework that posits Vibe magazine as a vehicle for disrupting mainstream press visual narratives about African Americans in general and black youth in particular. However, this oppositional reading requires an analysis of not just the cultural artifact, but also a discussion of audience reception as well as the intentions of the media makers. While some have argued that one cannot battle stereotypes from within mainstream media these media makers were able to circulate new ideas and images. Vibe reproduced patriarchal imagery of African American women, yet conversations with media makers indicate a conscious desire to disrupt such images. For this discussion, I draw on my larger analysis of early Vibe magazine covers as well as interviews with Vibe's founders and current media workers. Discussed here are motivations of the cover makers but also the cover image as a cultural artifact. One of the top fifty magazines in the U.S. in the 90's, Vibe helped to catapult hip-hop culture into the mainstream. The paper contextualizes Vibe within journalistic and political history, and critical race communication theories.
\end{abstract}

Keywords: Race and Representation, Hip-hop Journalism, Visual Communication, Vibe Magazine

$\mathrm{V}$

IBE MAGAZINE EXPLODED into the media scene in the 1990's. The glossy slick magazine, a partnership between music producer Quincy Jones and Time Inc., was a response to the massive rise in hip-hop music and culture. As well, Vibe editors pointed to the invisibility and misrepresentation of African Americans within mainstream news media as another reason for its creation. Analyses of interviews with media makers reveal that the desire to be recognized and respected drove much of the early year production at Vibe magazine. Many early media makers (writers, editors, photographers, publishers) of Vibe sought to counter the negative images they felt were projected by media at the time, not just of hip-hop but also of Black youth. Cultural theorist Mark Anthony Neal believed Vibe magazine was "a preeminent site for journalists and scholars chronicling contemporary black popular culture" (Neal, 2009).

An analysis of Vibe's 1994 TLC cover serves to provide an analytic framework to examine Vibe media makers' intentions as well as the circulation of their created images. I chose this cover for its ability to illustrate issues around gender, race, and mass media ${ }^{1}$. This cover emerged in Vibe's second year of production, the nascent stages of what is now a twentyyear-old magazine. Arguably, this cover represents the cusp of mainstream corporate jour-

\footnotetext{
${ }^{1}$ This analysis is part of a larger study of early Vibe magazine covers. A larger analysis is covered in another paper, as I do not have the space here to discuss all of the covers, nor the full historical, political and theoretical contexts.
} 
nalistic production of hip-hop's underground and collective sense of mission. That is, the Vibe TLC magazine cover, one of its best selling, illuminates and reflects issues surrounding the journalistic mainstreaming of hip-hop and with that, an increase in the circulation of the visuality of hip-hop journalism.

In one interpretation, Vibe created and circulated new images of African Americans both nationally and globally. Vibe projected glossy, aspirational and sophisticated images of racialized youth that quickly took hold in the popular imagination. In another interpretation, Vibe - directed by corporate owners - focused on marketable images and commercial success. In doing so, they reproduced normative and fixed images, packaging and selling a heterosexist, hyper sexualized idea of Black and urban youth to young audiences nationally and globally.

Irrespective of either interpretation, Vibe's commercial success meant that its covers were widely circulated and consumed by a generation of youth. This visibility, when before there was invisibility, represented a big shift in the New York, North American and global media landscapes.

\section{Images and the Other: Hip-hop Thugs and Jezebels}

Decades of research by cultural theorists have revealed widespread misrepresentation of African Americans in mass media. These critics - coming from feminist, African American and post-colonial studies - have pointed to a historical pattern of projection of rigid and limited representations of African Americans, reflecting a colonial script that reproduces the "other" in society (Hill Collins 2006, Mercer 1994, Bhabha 1999, Rose 1994). These images circulated stereotypes that projected Black men as hip-hop thugs, criminals, athletes and entertainers and Black women as nurturing mammies, promiscuous jezebels, feisty Sapphires, the welfare queens, among others. (Hill Collins 2006, Littlefield 2008, Mercer 1994, Rose 1994). As well, the criminalization of Black youth in news media has been well documented in both Canada and the U.S. (Harris-Perry 2011, Fleres \& Kunz 2001). Certainly, this mix of imagery suggests that African Americans have been present in North American cultural narratives. However, how do these narratives speak to audiences? And how do their audiences speak to the imagery?

Research has shown that audiences are vulnerable to having their opinions shaped by news, and images communicated in the news influence and inform our ideas and impact our view of the world (de Vreese 2010, Littlefield 2008, Fleras \& Kunz 2001). Therefore the cultural hegemony of news images impacts audiences - their self-identity, opinions and social discourse. For Black youth, these news media images have been overwhelmingly racist and negative (Harris-Perry, 2011). Yet hip-hop culture, as one of the major cultural influences of the last two decades, has exerted a visual identity that has resisted and challenged such framing. Hip-hop culture has provided "the visual markers for a larger cultural movement that has transformed popular music and international youth cultures in the last decades of the twentieth century" (Fleetwood 2011: 148)

\section{Images Speak but So Do Communities}

As cultural theorists have argued; readings or content analyses of cultural texts alone do not tell a complete story. Therefore, I conducted 12 open-ended interviews in order to analyze patterns related to discussions of the production, circulation and representation of racialized 
bodies on Vibe covers. My interview subjects were chosen for their significant involvement in covering hip-hop in New York. In this paper, I draw mostly from conversations with George Pitts, founding director of photography for Vibe and writer Joan Morgan. I also cite historical interviews as well as Vibe articles and letters to the editor. For this study, letters to the editor were one of the few ways I felt I could access audience reception.

As a former editor at Vibe (from 1997-1999), I am aware of the lure of nostalgia, which may influence my viewing of this subject. However, as a media scholar, I understand that scholarship may occur from many positions. Several examples of such insider scholarship exist within critical race communication theory. For example, Austin Long-Scott recalled his experience as a reporter during key civil rights moments to discuss stereotypes of African Americans in the press (2004). As well, Minelle Mahtani, a former producer for Canadian television, has explored journalism's lack of diversity from the perspective of content, newsroom culture, and audience reception (2009).

Vibe journalists were operating within the constraints of corporate interests, not public service ones. Therefore their ability to innovate within this hegemonic system raises questions. Can pop culture be a site of resistance? This question has been long debated within sociology and anthropology. Theorists such as Parsons posited that culture is a regulating force used to pacify the masses. Conversely, Gramsci (1971) treated popular culture as an anti-hegemonic or 'people's art' that "could potentially threaten the ruling class, whose hegemony was never permanent" (Collins 1992: 185). As Michelle Wallace argued, having fun with culture is one way to subvert the "deadly authority that runs our country and plagues our lives...At its worst however, mass culture can cajole us into buying what we've already got too much of: racism, sexism, American chauvinism, loving the rich and hating the poor" (Wallace 1990: 111). Still, within North America, mass media has governed the circulation of stereotypical images of racialized audiences. Austin Long-Scott has argued that journalists are unable to counter such stereotypes because of the constraints of their media system. Long-Scott's reasons include: corporate consolidation, the speed of journalism's deadlines, and an emphasis on a good story versus a thick one (2004). However, Wallace suggests that we approach Black mass and popular culture from the perspective of the producer as well as the audience in order to conduct a broad analysis. As well, Harris-Perry calls for an examination about the way Black women feel "as they wrestle with derogatory assumptions about their character and identity" (Harris-Perry, 2011). Therefore my investigation looks at Vibe holistically and emphasizes the intentions of the media makers as well as their historical and political contexts.

Though my questions focused on journalism produced from 1992 to 2008, my interview subjects often cited earlier years, especially when asked about their motivations for entering into the field of journalism. Many went back to early memories of their youth, living with music and culture they felt was invisible or misrepresented in the media. All cited stories they felt were covered with a racist lens. An analysis of interviews with Vibe media makers reveal that media makers felt a sense of mission and aimed to counter urban invisibility and also resist stereotypical normative images circulating in mass media. In doing so, Vibe not only chronicled a burgeoning hip-hop landscape at a crucial nexus in American history, but also, successfully disrupted the normative notion of the 'colonial other.' 


\section{Vibe and the Hip-hop Generation: Creating a Counter Narrative?}

There is much scholarship on the negative and misogynistic circulation of images created by hip-hop media. Many have suggested that images circulated about hip-hop focus too much on "bling" (consumer culture) and "gangsta" life or violent rivalry (Littlefield, 2008). Yet, an analysis of the interviews reveals that Vibe media makers produced images from a consciously oppositional lens. That is, Vibe journalists were aware of the stereotypes and also aware of their desire to disrupt such images.

Vibe started as a partnership between music producer Quincy Jones and Time Inc. in 1993 in order to capitalize on a growing youth market. However, its significance as a cultural vehicle demands examination beyond its corporate media position. Dan Charnas reveals a recollection by a journalist in a planning meeting with Time Inc. "Sandow [Greg Sandow, music director at the time at Entertainment Weekly]...was stunned during a meeting with Time Inc. executives when one of them asked directly, 'Do we really have to put Black people on the cover?" (Charnas, 2010: 451). A young Keith Clinkscales, publisher of small magazine called Urban Profile, was tapped as the CEO of Vibe. Clinkscales said he had got into publishing "to speak to some of the angst I had as a younger African American guy in New York: Trying to find a way to say, look all the things you write in the paper are not true. All the ways we are portrayed are not true. I just had a voice, and I wanted to get it out there... [With Vibe,] I got to see the power of culture and I got to compete for the first time. We competed with Rolling Stone. Rolling Stone!" (Clinkscales, 2011).

Visual theorist, Nicole Fleetwood noted the publication's significance. "[Vibe] served as a central site, along with music videos, for transmitting messages of the fashioned, and predominantly masculine, body of hip-hop (often through visual fantasies of material wealth and sexual excess) at the turn of the millennium" (2009: 163). And New York Times critic, David Carr wrote, "If there were no Vibe, contemporary black music and culture would not be quite so writ into the mainstream" (2009).

James Scott (1990) set the stage for a discussion about resistance within media in his book, Everyday Resistance. Scott explained that culture - when it is conducted or shown off stage - could contain hidden (and subversive) transcripts. In Scott's idea of everyday resistance, a community that is misrepresented in the press responds to its system of racist images by resisting dominant transcripts in subtle but hidden ways. Even though Vibe magazine was part of the on-staging of hip-hop culture, making hyper visible to mainstream what may have been invisible before, it is still pertinent to search for the hidden transcripts which contradict and subvert dominant ideological positions. Although rap music was quickly becoming the new popular choice of music, as indicated by music sales, news media attention on rap fixated on instances of violence and not commercial success (Rose, 1994).

Bakari Kitwana, editor at the Source magazine in the 1990s, used the term, "hip-hop generation" (2002) in order to articulate a nuanced political and cultural position for African American youth within Generation X. Born between 1965 and 1984, this generation had a collective sociopolitical set of cultural values that differed from the previous. Also called the "post-soul" generation, they grew out of the Civil Rights and Black Power movements, with its victories, promises and colossal disappointments (Neal, 2002). These were Reagan and Bush years to grow up in: Reagan was opposed to the landmark civil rights bill from 1968 and vetoed a 1988 Bill that expanded federal civil rights. "Throughout his career, Reagan was wrong, insensitive and mean-spirited on civil rights and other issues important to black 
people," Bob Hebert, New York Times columnist wrote (2007). It was within this cultural milieu that hip-hop generation writers, scholars, filmmakers, artists and activists laid the foundation for a new cultural stance. It is difficult now to imagine Black youth as a nearly invisible entity in American popular culture, but prior to the rise of hip-hop, that was the case. Vibe's ideas and images were received by audiences at a time when Black youth were seen either as a "nearly invisible entity in American popular culture" or as a population visible "mostly during the six o'clock evening news reports of crime in urban America" (Kitwana 2002: 196).

\section{Vibe's TLC Cover}

The Vibe cover depicts multiplatinum 'girl rap group,' TLC in firefighter uniforms. The cover was a departure for Vibe covers up to that point - which had mostly depicted Spartan and beautiful portraits of the new urban music stars. Urban had become almost a code word for Black by the 1990s, but 'urban' was multicultural, transnational and marketable. The cover photo illustrates the feature story, "The Fire This Time," by Joan Morgan. The tagline to the story read: "TLC led the first wave of B-girl feminism." The editor in chief at the time was Alan Light and George Pitts, the director of photography. Dah Len took the TLC photos for this issue in August 1994 (Atlanta, Georgia). The cover (below) reveals a different story than just any other "B-girl" group."

While it may appear on the surface that the women of Vibe were simply derivative sexualized images, interviews with Vibe editors reveal subversive intentions. The image makers were aspirational and were attempting to rupture and disrupt existing boundaries around the representation of racialized youth in American news media.
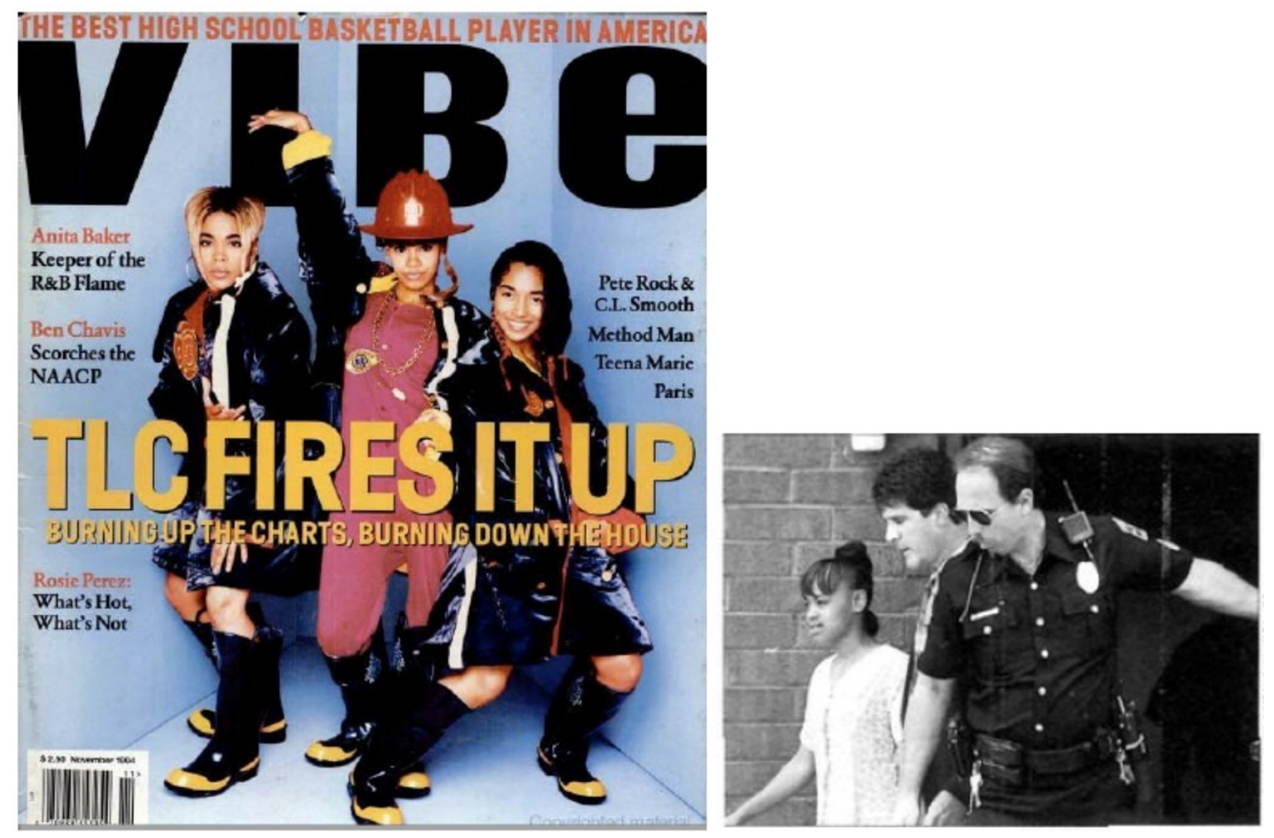

Above: Vibe cover, November 1994 (left); Lisa “Left Eye” Lopes, People magazine, June 271994 (right) 
Vibe writer Joan Morgan (1994) had spent six days with TLC reporting their story, trying to tell the story of TLC from a different perspective than she had so far encountered. Most everyone was calling Lisa "Left Eye" Lopes crazy for setting her cheating boyfriend's house on fire ${ }^{2}$. In her feature, Morgan explained that it was reductionist media coverage and not the fire that drew her to Atlanta to explore and tell TLC's story. She wrote that the sound bites about TLC member Left Eye "made nice little tidbits to be broadcast between replays of O.J's low-speed freeway chase and the obligatory lip service paid to preventing domestic violence. But that was about all we heard...neither Lopes' accomplishments nor her expression of rage is a very sexy topic. There seems to be little or no interest in the circumstances."

What Lopes had done was set her NFL star boyfriend's tennis shoe on fire in their bathtub. According to the story as told by Morgan, her boyfriend had beaten her that night. Unfortunately, the bathtub was made of plexiglass and, as fires do, the flame spread throughout their shared mansion. "I was just trying to barbecue his tennis shoes," Lopes later explained (Last Days of Left Eye, 2007). "There is no way in the world that I would have intentionally started that fire" (Vibe, 1994). Discussing the cover more than 15 years later, Morgan said: "Lisa's no longer here so that makes me $\mathrm{sad}^{3}$. My whole angle in doing this story was so many people were writing about her 'she's crazy, she burned the house down,' but I wanted more from the story. I really wanted to cover it from the point of 'when have I been crazy' or 'in a relationship that makes you crazy.' She had been punched around a lot by him and she had also done some stuff that was insane but not inhuman. That was one of the times when the writer helped with the image and I had no idea that was going to be the image. The girls were pretty upset. I don't know why if they were going to be upset about it they would put the clothes on in the first place. Yeah, 'burning up the charts and burning down the house.' It sold. And as a magazine person I still think it's a genius cover."

Vibe readers, through Joan Morgan's eyes, read about Lopes and TLC from Morgan's oppositional perspective. Stuart Hall (1993) might call Morgan's journalism at that time a "strategic contestation." Morgan was interested in telling Lopes' story from an everyday perspective - even within the narrative defined by corporate journalism. Morgan recalls not being aware of corporate restrictions in her early days at Vibe: "I think about some of the ways we conducted ourselves in the office and it was completely wrong and radical but it produced really good journalism. None of us had quite learned how to be corporate yet. One time I remember a really sexual ad and everyone in editorial was upstairs and everyone in business was downstairs and there was a petition. I wouldn't even bother to think about that now because that separation of editorial and business is non-existent now. We were passionate about hip-hop culture because there was a feeling that we were the authentic voices and we weren't these Ivy League white suburban music nerds" (personal communication, May 2011).

Morgan said she got into journalism after reading an article in New York weekly, the Village Voice. The article, she said, created a desire to add what she thought was missing from the media mix: a young black feminist perspective. She said: "I had to make it make sense in my life which was immersed in a culture that a lot of people thought was very misogynistic and at times really is... Our experiences at that time were so influenced by hiphop, including discussions about class or discussions about race; it was a very embryonic

\footnotetext{
${ }_{2}^{2}$ Eg. coverage from People magazine, $\mathrm{CNN}$ and the Philadelphia Inquirer

${ }^{3}$ Lopes died in a car accident in 2002.
} 
kind of time. I felt like there was a new narrative emerging, one that hip-hop played a vital role in. I never stood inside the frame and to me that point of interrogation into both hip-hop and feminism was always standing outside and a little uncomfortable but I think it's a valuable position because in order to survive I have always had to balance multiple identities at the same time" (Morgan, 2000 and personal communication, May 2011).

Morgan's quote exemplifies what Harris-Perry might call the internalization of politics for Black women. Harris-Perry argues that Black women must negotiate, resist and accommodate negative assumptions and stereotypes in order to preserve their authentic selves. What might not at first seem like an overtly political text may reveal gender and racial politics (Harris-Perry, 2011).

The campy depiction of Left Eye's breakdown-wearing a fire fighter uniform on the cover of a magazine - after setting her boyfriend's house on fire made light of Lopes' trouble with the law, forever, changing TLC's visual imprint in mass media. However campy and cartoonish it may be considered, this photo places women in a position of power. All three women are wearing rubber boots and protective slickers. Lisa Lopes is wearing a protective hard hat-perhaps a metaphor for the abuse of her image in other media outlets? She's wearing a gold medallion-African medallions were a common visual cue in hip-hop fashion at the time; Lopes' medallion looks like it is a city official fire department medallion - but, like the hip-hop medallions at the time, it is strung around a gold chain. All the women are fully covered and all three women are looking directly at the spectator. Lisa Lopes is in a fully body suit - the kind of protective armor worn by firefighters. By depicting them as firefighters, Vibe has placed TLC above the law but also acknowledges that media depictions of Lopes acted as a type of law in society that needs to be broken. Vibe founding director of photography George Pitts said: "It's a witty and conscience - some would say naughty —illusion to what these particular artists were embroiled in... We had in our brainstorming ideas a desire to go in this direction but since this was one of the first really pointed magazine covers we weren't really sure that the subjects would sign on to it."

At the time, Vibe presented a powerful counter-narrative to dominant images of AfricanAmericans. The story of Lisa Lopes and TLC was circulated in the public via news sites like $\mathrm{CNN}$; such images reinforced white privilege and replicated stereotypical, negative images of African-Americans. The image of Lisa Lopes being carted off by the police in People is one such example. The public circulation of the counter image might be considered an articulation of pride and defiance (Fleetwood, 2011). Although the media makers were operating within the constraints of corporate media, there were strategic decisions to subvert existing representations. The decisions were not always obvious and they were not always a clear act of resistance, but perhaps they can be read as small alterations, or diversions from historical scripts. Some ideas were successful and evoked powerful responses from readers. In the case of the TLC cover, Vibe audiences had the opportunity to envision their celebrities - representatives of many young black women at the time - differently than mainstream news portrayals.

Pitts said, "I don't think we had a formula as much as we had a collectively sophisticated mandate to create enduring visuals." While successes to disrupt hegemonic images are limited - some images work to rupture existing narratives and others simply replicate them - the discussion about the increased visibility of black youth in media as a result of magazines like Vibe must remain complex and nuanced and take into account the oppositional positions of its media makers. Looking back George Pitts said he feels Vibe needs a place in journal- 
ism's history books. He said, "We created visuals that endured for [our] core community, the core readership but also visuals that would persuade mainstream and world culture that we as editors are capable of working in the same arena of ambition that they existed in but also that we could honor celebrate and represent with compassion and journalistic intelligence this community which [they] had not at that juncture found the most advanced and empathetic ways to represent in publications."

\section{Acknowledgments}

Thank you to Associate Professor Michelle Stack, UBC (education and journalism) and former Vibe editor Andrew Gillings for their guidance with this paper. Also, thank you to my Research Assistants, Tishana Arnold and Boké Saisi. 


\section{References}

Bhabha, Homi K. (1999). The other question: The stereotype and colonial discourse. In Visual culture: The reader., eds. Jessica Evans, Stuart Hall, 370-378. London: SAGE Publications.

Carr, David. (2009). Vibe magazine, showcase for hip-hop and R\&B, dies at 16. The New York Times, pp. 1. Retrieved from http://www.nytimes.com/2009/07/02/arts/music/02vibe.html

Charnas, Dan. (2010). The big payback: The history of the business of hip-hop. New York: New American Library.

Clinkscales, Keith. "ESPN's Keith Clinkscales on success, failure and redemption" in Folio. Posted to http://www.foliomag.com/video/espns-keith-clinkscales-success-failure-and-redemption

de Vreese, C. H. (2010). “The effects of journalistic news frames.” In P. D'Angelo \& J. Kuypers (Eds.), Doing Framing Analysis. Routledge.

Fleetwood, Nicole R. (2011). Troubling vision: Performance, visuality, and blackness. Chicago: The University of Chicago Press.

Fleres, A. \& Kunz, J. L. (2001). Media and minorities: Representing diversity in a multicultural Canada.

Gramsci, Antonio. (1971). Selections from the prison notebooks of antonio gramsci, eds. Quintin Hoare, Geoffrey Nowell-Smith. 1st ed. ed. New York: International Publishers.

Hall, Stuart. "What is this "black" in black popular culture?" Social Justice, Spring-Summer $1993 \mathrm{v}$ 20 no1-2.

Harris-Perry, Melissa. (2011). Sister Citizen: Shame, Stereotypes and Black Women in America. New Haven: Yale University Press.

Herbert, Bob. Righting Reagan's Wrong's? Opinion. New York Times. November 13, 2007. http://www.nytimes.com/2007/11/13/opinion/13herbert.html

Hill Collins, Patricia. (2006). From black power to hip-hop: Racism, nationalism, and feminism. Philadelphia: Temple University Press.

Kitwana, Bakari. (2002). The hip-hop generation: Young blacks and the crisis in African American culture. 1st ed. ed. New York: BasicCivitas Books.

Littlefield, Marci Bounds. (2008). The media as a system of racialization: Exploring images of african american women and the new racism. American Behavioral Scientist 51 (5) (01): 675-85.

Long-Scott, Austin. (2004). Understanding race, class and urban violence: Why journalists can't do more to help us understand. Race, Gender and Class, 11(1), January 19, 2011-6-22.

Mahtani, Minelle. (2009). Critiquing the critiques about media and minority research in Canada. Canadian Journal of Communication, 34(4), 715-715-719.

Mercer, Kobena. (1994). Welcome to the jungle: New positions in black cultural studies. New York: Routledge.

Morgan, Joan. (2000). When Chickenheads Come to Roost: A hip-hop feminist breaks it down. Trade Paperback ed. New York: Simon \& Schuster.

Neal, Mark Anthony. (2009). Missing an icon. The New Black Magazine. October 6 2009, http://www.thenewblackmagazine.com/view.aspx?index $=2129$.

Neal, Mark Anthony. (2002). Soul babies: Black popular culture and the post-soul aesthetic. New York: Routledge.

Rose, Tricia. (2008). Hip-hop is not responsible for sexism. In The hip-hop wars: What we talk about when we talk about hip-hop--and why it matters., 153. New York: BasicCivitas.

Rose, Tricia. (1994). Black noise: Rap music and black culture in contemporary America. Hanover, NH: University Press of New England.

Scott, J. C. (1990). Domination and the arts of resistance: Hidden transcripts. New Haven: Yale University Press.

Stack, Michelle, and Deirdre M. Kelley. (2006). Popular media, education and resistance. Canadian Journal of Education 1 (29): 5. 
Stephens, Mitchell. (1998). The rise of the image, the fall of the word. New York: Oxford University Press.

The Last Days of Left Eye. Dir. Lauren Lazin. VH1, (2007). Film.

Wallace, Michelle. (1990). Invisibility Blues: From Pop to theory. New York: Verso Press.

\section{About the Author}

Vinita Srivastava

I am currently an assistant professor at the Ryerson University School of Journalism in Toronto, Canada and the director of the Verse City Project designed to encourage youth participation in media. I spent a good part of the 90's in the New York publishing industry, both within the urban media industry (Vibe, Impact, Honey) and mainstream media (the New York Times). I have also reported for the Village Voice and was co-host and producer of the Asia Pacific Forum on WBAI Radio, NYC. As an insider whose global positionality is oftentimes outside, I hope to reveal the significance of race in these types of institutions along with the ongoing media challenges and debates. On a larger scale, this investigation will seek to answer: Where are the remaining urban media outlets? Who are their audiences? What images are getting circulated? And what are these images projecting? As social media use grows and traditional media declines, what networks are being created by and for urban journalists? 


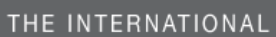 \\ JOURNAL Of THE IMAGE}

\section{Editors}

Phillip Kalantzis-Cope, The New School for Social Research, New York, USA.

Tamsyn Gilbert, The New School for Social Research, New York, USA.

\section{Editorial Advisory Board}

Tressa Berman, California College of the Arts, San Francisco, USA;

UTS-Sydney, Australia

Howard Besser, Tisch School of the Arts, New York University, New York City, USA

Sean Cubit, The University on Melbourne, Melbourne, Australia

Owen Evans, Edge Hill University, Ormskirk, UK

Tamsyn Gilbert, The New School for Social Research, New York City, USA

Dina lordanova, Provost, St Leonards College, University of St Andrews, Scotland

Douglas Kellner, University of California, Los Angeles, USA

Phillip Kalantzis-Cope, The New School For Social Research, New York City, USA

Gunther Kress, Institute of Education, University of London, London, UK

Emanuel Levy, Professor/Author/Critic, University of California, Los Angeles, USA

Mario Minichiello, Birmingham Institute of Art and Design, Birmingham, UK

Colin Rhodes, Sydney College of the Arts, University of Sydney, Sydney, Australia

Becky Smith, School of Theater, Film and Television, University of California, Los

Angeles, USA

Marianne Wagner-Simon, Director, Freies Museum Berlin, Germany

Please visit the Journal website at http://www.OnThelmage.com for further information about the Journal or to subscribe. 


\section{The Image Community}

This knowledge community is brought together around a common shared interest in the role of The Image. The community interacts through an innovative, annual face-to-face conference, as well as year-round virtual relationships in a weblog, peer reviewed journal and book imprint - exploring the affordances of the new digital media.

\section{Conference}

Members of The Image Community meet at The International Conference on the Image held annually in different locations around the world. The 2010 conference was held at the University of California, Los Angles, USA and in 2011the conference will be held at the Kursaal Congress Palace, San Sebastian, Spain.

Online presentations can be viewed on YouTube.

\section{Publishing}

The Image Community enables members to publish through three media. First by participating in The Image Conference, community members can enter a world of journal publication unlike the traditional academic publishing forums - a result of the responsive, non-hierarchical and constructive nature of the peer review process. The International Journal of the Image provides a framework for double-blind peer review, enabling authors to publish into an academic journal of the highest standard.

The second publication medium is through the book series The Image publishing cutting edge books in print and electronic formats. Publication proposal and manuscript submissions are welcome.

The third major publishing medium is our news blog, constantly publishing short news updates from The Image Community, as well as major developments in the various disciplines of the image. You can also join this conversation at Facebook and Twitter or subscribe to our email Newsletter. 


\section{Common Ground Publishing Journals}

\begin{tabular}{|c|c|}
\hline $\begin{array}{l}\text { AGING } \\
\text { Aging and Society: An Interdisciplinary Journal } \\
\text { Website: http://AgingAndSociety.com/journal/ }\end{array}$ & $\begin{array}{c}\text { ARTS } \\
\text { The International Journal of the Arts in Society. } \\
\text { Website: www.Arts-Journal.com }\end{array}$ \\
\hline $\begin{array}{l}\text { BOOK } \\
\text { The International Journal of the Book } \\
\text { Website: www.Book-Journal.com }\end{array}$ & $\begin{array}{c}\text { CLIMATE CHANGE } \\
\text { The International Journal of Climate Change: } \\
\text { Impacts and Responses } \\
\text { Website: www.Climate-Journal.com }\end{array}$ \\
\hline $\begin{array}{c}\text { CONSTRUCTED ENVIRONMENT } \\
\text { The International Journal of the } \\
\text { Constructed Environment } \\
\text { Website: www.ConstructedEnvironment.com/journal }\end{array}$ & $\begin{array}{c}\text { DESIGN } \\
\text { Design Principles and Practices: } \\
\text { An International Journal } \\
\text { Website: www.Design-Journal.com }\end{array}$ \\
\hline $\begin{array}{c}\text { DIVERSITY } \\
\text { The International Journal of Diversity in } \\
\text { Organizations, Communities and Nations } \\
\text { Website: www.Diversity-Journal.com }\end{array}$ & $\begin{array}{l}\text { FOOD } \\
\text { Food Studies: An Interdisciplinary Journal } \\
\text { Website: http://Food-Studies.com/journal/ }\end{array}$ \\
\hline $\begin{array}{c}\text { GLOBAL STUDIES } \\
\text { The Global Studies Journal } \\
\text { Website: www.GlobalStudiesJournal.com }\end{array}$ & $\begin{array}{c}\text { HEALTH } \\
\text { The International Journal of Health, } \\
\text { Wellness and Society } \\
\text { Website: www.HealthandSociety.com/journal }\end{array}$ \\
\hline $\begin{array}{c}\text { HUMANITIES } \\
\text { The International Journal of the Humanities } \\
\text { Website: www. Humanities-Journal.com }\end{array}$ & $\begin{array}{c}\text { IMAGE } \\
\text { The International Journal of the Image } \\
\text { Website: www.Onthelmage.com/journal }\end{array}$ \\
\hline $\begin{array}{l}\text { LEARNING } \\
\text { The International Journal of Learning. } \\
\text { Website: www.Learning-Journal.com }\end{array}$ & $\begin{array}{c}\text { MANAGEMENT } \\
\text { The International Journal of Knowledge, } \\
\text { Culture and Change Management. } \\
\text { Website: www.Management-Journal.com }\end{array}$ \\
\hline $\begin{array}{c}\text { MUSEUM } \\
\text { The International Journal of the Inclusive Museum } \\
\text { Website: www.Museum-Journal.com }\end{array}$ & $\begin{array}{c}\text { RELIGION AND SPIRITUALITY } \\
\text { The International Journal of Religion and } \\
\text { Spirituality in Society } \\
\text { Website: www.Religion-Journal.com }\end{array}$ \\
\hline $\begin{array}{c}\text { SCIENCE IN SOCIETY } \\
\text { The International Journal of Science in Society } \\
\text { Website: www.ScienceinSocietyJournal.com }\end{array}$ & $\begin{array}{c}\text { SOCIAL SCIENCES } \\
\text { The International Journal of Interdisciplinary } \\
\text { Social Sciences } \\
\text { Website: www.SocialSciences-Journal.com }\end{array}$ \\
\hline $\begin{array}{c}\text { SPACES AND FLOWS } \\
\text { Spaces and Flows: An International Journal of } \\
\text { Urban and ExtraUrban Studies } \\
\text { Website: www.SpacesJournal.com }\end{array}$ & $\begin{array}{c}\text { SPORT AND SOCIETY } \\
\text { The International Journal of Sport and Society } \\
\text { Website: www.sportandsociety.com/journal }\end{array}$ \\
\hline $\begin{array}{c}\text { SUSTAINABILITY } \\
\text { The International Journal of Environmental, Cultural, } \\
\text { Economic and Social Sustainability } \\
\text { Website: www.Sustainability-Journal.com }\end{array}$ & $\begin{array}{c}\text { TECHNOLOGY } \\
\text { The International Journal of Technology, } \\
\text { Knowledge and Society } \\
\text { Website: www.Technology-Journal.com }\end{array}$ \\
\hline $\begin{array}{c}\text { UBIQUITOUS LEARNING } \\
\text { Ubiquitous Learning: An International Journal } \\
\text { Website: www.ubi-learn.com/journal/ }\end{array}$ & $\begin{array}{l}\text { UNIVERSITIES } \\
\text { Journal of the World Universities Forum } \\
\text { Website: www.Universities-Journal.com }\end{array}$ \\
\hline
\end{tabular}

For subscription information please contact subscriptions@commongroundpublishing.com 